\title{
The ontogeny of, and relationships between, Middle Miocene and Quaternary Orbulina (Foraminifera)
}

\author{
DAMINI DESAI \& F. T. BANNER \\ Postgraduate Unit of Micropalaeontology, Department of Geology, University College London, \\ Gower Street, London WC1E 6BT
}

\begin{abstract}
The early, coiled stages of Orbulina suturalis and O.universa are described from both Middle Miocene (zones N9-N12) and Quaternary samples. The coiling mode of Orbulina is unique to that genus, and has remained unchanged (as have the spines characteristic of the coiled growth stage) since that genus and its species first evolved.Orbulina universa is monophyletic and its evolutionary history appears to provide an example of "punctuated equilibria" in the development of Cainozoic Globigerinacean development. "O. suturalis", on the other hand, appears to be a name which has been applied both to the Middle Miocene species and to phylogenetically different forms of Quaternary age.
\end{abstract}

\section{INTRODUCTION}

Over three decades ago it was recorded that the first stratigraphical appearance of abundant Orbulina in the far eastern Neogene was a valuable correlative horizon (Le Roy, 1948). The appearance of abundant Orbulina in the marly facies of the Miocene of Papua indicated to Glaessner and others a Middle Miocene age (Australasian Petroleum Company, 1961). Eames et al. (1962) considered that Orbulina first appeared at a high level in the Aquitanian, Early Miocene, not only in the Far East but also throughout the tropical world. Adams (1970) cast doubts upon this and noted that there were no confirmed occurrences of Orbulina below beds of Middle Miocene age. However, the recognition by Blow (1956) that the evolution of Orbulina, rather than merely the first facies controlled appearance, could prove to be a most valuable biostratigraphical index horizon, has been borne out by much subsequent work and firmly dated as an event virtually comtemporaneous with the Early Miocene/Middle Miocene boundary (Berggren \& Van Couvering, 1974; Kennett \& Srinivasan, 1983). The evolution of Globigerinoides trilobus (Reuss) to $G$. bisphericus Todd to Praeorbulina sicana (de Stefani) to $P$. glomerosa (Blow) (all in zone $\mathrm{N} 8$ ) to $O$. suturalis (N9) has again been described, with some taxonomic and zonal redefinition, by Jenkins et al. (1981). It is likely that the evolution of $O$. suturalis Brönniman from its immediate ancestor, Praeorbulina glomerosa circularis (Blow), which has now been well documented by Fleming et al. (1969), occurred over a very short interval of geological time - possibly as little as 100,000 years (Banner \& Lowry, in press). The evolution of $O$. universa d'Orbigny from $O$. suturalss, equally well documented (Fleming et al., op. cit.) probably occupied an equally short duration. The first evolutionary appearance of $O$. suturalis was used by Banner \& Blow (1965) to define the base of planktonic foraminiferal zone N9, a definition which was maintained by Blow
(1979) and by Jenkins et al . (1981); it has been adapted as the criterion for recognition of the base of the Middle Miocene in tropical pelagic facies (e.g. Vincent, 1977; Berggren, 1982).

Both $O$. universa and $O$. suturalis are recorded in the present day Oceans although $O$. suturalis is now relatively very rare. The type specimens of $O$. universa are from the Recent of the Caribbean (refigured by Le Calvez, 1977) and the species is widely distributed in Recent sediment of the world's ocean, especially in the north and south Atlantic (Bé, 1977). In contrast, $O$. suturalis was first described from the Cipero formation of Trinidad (Brönnimann, 1951; Blow, 1956), which is of Middle Miocene age (the same age as the type horizon of "Candorbulina universa" (Jedlitschka), its junior synonym). All records of $O$. suturalis seem to show that it is abundant in the Middle Miocene but rare in younger horizons. Its very existence in the Quaternary has been doubted. Vilks \& Walker (1974), in plankton hauls from the Atlantic, Pacific and Caribbean, found only three specimens which could be referred to this species because the spiral test penetrated the enclosing sphere. They noted that the spiral stage of these specimens had round, cylindrical spines only, unlike the triradiate spines of $O$. universa, and suggested "that the forms resembling $O$. suturalis Brönnimann (1951) and living in the present day Oceans are aberrant Globigerina bulloides". Bé \& Okada (1973) and Bé et al. (1973) also studied Recent $O$. universa in SEM and found that the spiral stage of this species consistantly possessed triradiate spines, even though those of the sphere are rounded - cylindrical. Much emphasis has been placed in recent publications on the phyletic significance of the types of spine. Saito et al. (1981) define the Globigerinatype as having a round spine-base and round spine, the Globigerinella-type with a round-triangular base and a rounded-triangular spine which becomes triradiate distally, and the Hastigerina-type which is triradiate 
throughout and is barbed. These criteria were used to distinguish separate families - the first two representing the Globigerinidae and the last the Hastigerinidae. On this basis, modern $O$. universa and " $O$. suturalis" could be referred to separate families, at least in their spiral stages of ontogeny.

These observations raise several questions. Is "O. suturalis" of the Quaternary the same as the true $O$. suturalis of the early Middle Miocene? When did the triradiate spinosity of $O$. universa evolve? Did it appear with the first Orbulina or did it evolve during the 16 million years since the first appearance of Orbulinid coiling? Many evolving lineages of the Globigerinacea clearly show recapitulation of ancestral coiling and chamber characters in the early ontogeny of stratigraphically later forms (e.g. Banner \& Lowry, in press). Does modern Orbulina recapitulate the growth mode of Middle Miocene Orbulina, and does the latter recapitulate that of the ancestral Globigerinoides? Has there been an evolutionary equilibrium since the earliest Middle Miocene or has progressive evolution continued in the coiling mode and other characters of the spiral stage of Orbulina? Are $O$. suturalis and $O$. universa of Middle Miocene zone N9 the same as the Recent foraminifera which are identified by these names? Hof ker (1969), Bandy (1966) and Bandy et al. (1969) have independently suggested that Orbulina is a polyphyletic genus, having evolved a terminal spherical chamber from different species of Globigerina and Globigerinoides. Scott (1973) attempted to interpret the gross coiling of Praeorbulina and both Miocene and Recent Orbulina in terms of a mathematical model but he did not examine the earliest growth stages or the spinosity of any of these forms; he did not distinguish $O$. suturalis and he provided little hard data to substantiate his conclusion that polyphyleticism in the Orbulina lineage is unlikely.

In attempt to answer some of these questions we have dissected $O$. suturalis and $O$. univers $a$ from the early to middle part of zone N9, earliest Middle Miocene, and we describe the ontogenetic development of these taxa from specimens representing the earliest forms of the genus Orbulina. They are compared with Recent spccimens both dissected afresh and as described in the literature.

\section{MATERIALS AND METHODS}

Orbulina was obtained from samples collected from the Cipero formation of Trinidad (near topotypes of $O$. suturalis), from the early Middle Miocene successions of Malta and from Holocene sediments of the Nigerian continental shelf and the eastern Mediterranean.

From Trinidad, samples were examined from Hermitage Quarry, the type locality of the "Globorotalia fohsi barisanensis zone" of Bolli (1957, p. 101), and of the "Orbulina suturalis - G. peripheroronda partial range zone", N9 of Blow 1979, p. 32): other material from this zone came from its radiolarian facies exposed along the Philippine Road. Also from Trinidad we examined a sample from a type locality of the "Globorotalia fohsi fohsi zone",Golconda Estate (Bolli, 1957 , p. 101), which is the "G. praefohsi zone", zone N11 (Blow, 1979, p. 37, p. 38), and a sample from approximately the type locality of the "Globorotalia fohsi lobata zone", Cipero Road section of Bolli (1957, p. 101), which is referable to the $G$. fohsi zone, zone N12 (Blow, 1979, p. 41, 42). These samples span the early to middle parts of the Middle Miocene, approximately from 16 to 13.5 mya (Banner \& Lowry, in press).

In Malta, the Sara Valley section, $6.4 \mathrm{~km}$ from the citadel, exposes 3.4 metres of pelagic grey clays below the Globigerina limestone; the lowest exposed clays (U.C.L. sample no. 6733) contained abundant $O$. suturalis and are referable to early zone $N 9.30 \mathrm{~m}$ of the Globigerina limestone is exposed in the base of the cliff section in Fomm-ir-Rih bay, western Malta, $0.8 \mathrm{~km}$ from the southern limit of the embayment, and above the limestone is exposed another $30 \mathrm{~m}$ of the Malta Blue Clay. The Globigerina limestone has been dated by Blow (1957) and by Eames et al. (1962) as highest Early Miocene; the Blue Clay, which succeeds the limestone without unconformity or diastem, was recorded by Blow (1957) to contain an assemblage "identical with that of the Globorotalia fohsi barisanensis subzone as seen in the Cipero formation of southern Trinidad". We can confirm that the lower part of the Blue Clay, with $O$. suturalis and $O$. universa, is of middle to late zone $\mathrm{N} 9$ age, but the highest part of the section (U.C.L. sample no. 5455) also contains Globorotalia peripheroacuta and belongs to zone $\mathrm{N} 10$.

Piston cores were taken from the Aegean Sea by a U. C. Swansea Oceanography department team in 1982; the cores contained a sapropelic pelagic marl, referable to the earliest Holocene, which yielded $O$. univers $a$ and rare " $O$. suturalis". These forms were also retrieved from gravity core and piston core samples of Recent sediment obtained in 1959 from the outer continental shelf of Nigeria by Shell International Research Maatschappij B. V. and the British Petroleum Co. Ltd.

About 200 specimens were dissected using a fine needle, then coated with gold and photomicrographed with a Jeol JSM - T200 SEM at 10-15 Kv. They were then further dissected, recoated and rephotomicrographed. Some specimens (e.g. Pl. 1, fig. 3, 11; Pl. 2, fig. 2) were embedded in Lakeside 70 thermoplastic, opened by cutting with a scalpel, gold-coated and scanned.

\section{OBSERVATIONS}

\section{The ontogeny of Middle Miocene Orbulina}

The earliest whorl, in both $O$. suturalis and $O$. universa, has more than four chambers surrounding the pro- 


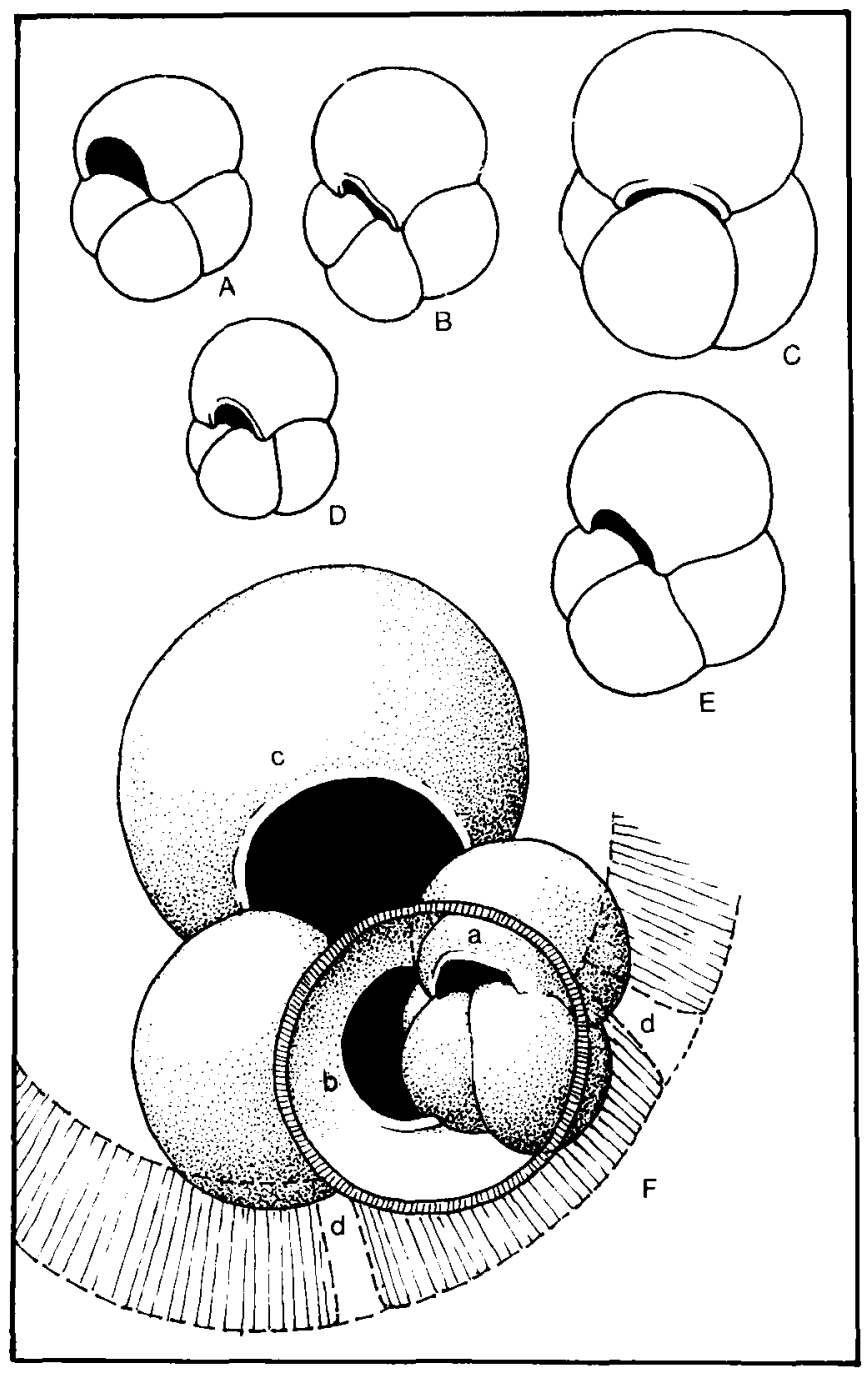

Fig. 1. Comparative apertural views of early, fourchambered whorls of the early Middle Miocene Orbulina test, all drawn to the same scales. A-C, $O$. suturalis, showing variation from a high pseudointra-extraumbilical primary aperture (A, compare Pl. 1, fig. 4b) to a low, more pseudoumbilically restricted aperture (B, compare Pl. 1, figs. 2a, 3) and to a low aperture entirely restricted to the area of the pseudoumbilicus (C, compare Pl. 1, fig. 8b) $\mathrm{D}-\mathrm{E}, O$. universa, comparable successive growth stages in which the aperture remains extended beyond the pseudoumbilicus (D, compare Pl. 1, fig. $6 \mathrm{~b}$; E, compare Pl. 1, fig. 5b). F, the disposition of the early whorls of a specimen of $O$. suturalis (compare Pl. 1, fig. 9a) where the variation in apertural extent is also an ontogenetic progression. The successive whorls are streptospiral from an early stage (a) (compare fig. 1c), in which the final chamber becomes the first of the succeeding (last) whorl; the septal aperture of the next (the antepenultimate) chamber (b), is at about $180^{\circ}$ to the plane of the final aperture (c); the position of two of the supplementary apertures of the enclosing sphere is also shown (d). No single straight axis of coiling can accommodate this chamber and apertural sequence, and there is no umbilicus into which the primary apertures all open.

loculus (P1. 1, fig. 1b) and is dorsoventrally compressed, with a rounded-angular periphery. By the end of the second whorl, the chambers become sub-globular and there are only four in each whorl. The umbilical ends of the chambers meet (e.g. Pl. 1, figs. 3, 4, 5) or even slightly overlap to embrace each other ( $\mathrm{Pl}$. 1, figs. 2a, 6b), in each case closing the umbilicus to produce an "umbilical depression" (sensu Reiss, 1960, p. 11). As there is no true umbilicus (sensu Reiss, 1960; Blow, 1979), the primary aperture is extra-umbilical. It extends from the umbilical depression to the periphery (PI. 1, figs. 2a, 3, 4b, 5b, 6, $12 \mathrm{~d}$ ), giving the test a "Globorotaline" appearance. The pseudoumbilical - extraumbilical aperture may persist until the penultimate whorl of the spire (e.g. Pl. 1, figs. $11,12 \mathrm{~d})$, but, in both $O$. suturalis and $O$. universa, the ventrally directed coiling may lead to such a degree of chamber embrace over the umbilical depression that the primary aperture becomes restricted to that depression and becomes pseudo-intraumbilical (Pl. 1, figs. 8b, 9b; Pl. 2, fig. 10b). The early closure of the umbilicus and the migration of the aperture from an extraumbilical to the pseudo-intraumbilical position is a clear expression of increasingly ventrally-directed streptospirality, in which the chambers increasingly embrace each other on the ventral side of the spire. The closed umbilicus prevents the relict apertures of earlier chambers from opening directly to the exterior through an umbilical cavity: instead, they are merely septal apertures opening from one chamber into the next - this is clearly seen in PI. 1, fig. $9 \mathrm{~b}(O$. suturalis) and Pl. 2, fig. $10 \mathrm{~b}(O$. universa, Fig. $1 F)$. The ontogenetic development of streptospirality and apertural migration exactly parallels that seen in Pulleniatina obliquiloculata (Banner \& Blow, 1967, especially Pl. 2, figs. 4-7). The early pseudointraextraumbilical primary aperture of the first and second whorls of $O$. suturalis (Pl. 1, figs. 3 and $4 \mathrm{~b}$; figs. 1A, B) is analogous to the early aperture of $P$. obliquiloculata (Banner \& Blow, 1967, Pl. 2, figs. 4-5; Huang, 1981. Pl. 5, figs. 52, 53). The pseudoumbilically more restricted later aperture (shown in $\mathrm{Pl}, 1$, fig. 2a) parallels that in $P$. obliquiloculata at a similar growth stage (Banner \& Blow, op. cit., pl. 2, fig. 6) and the pseudointraumbilical aperture of the first chamber of the last whorl (PI. 1, fig. $8 b$ ) is matched by a similarly restricted aperture in the first chamber of the last whorl of $P$. obliquiloculata (Banner \& Blow, op. cit., pl. 2, fig. 7). In each case, yet later chambers of the last whorl again extend the primary aperture to a pseudointra-extraumbilical position 


\section{Explanation of Plate 1}

The development of the spire in Middle Miocene Orbulina: SEM micrographs of dissected specimens. Figs. 1-4, 7-12, $O$. suturalis; figs. $5,6, O$. universa.

Fig. 1. O. suturalis from base of exposed Grey Clay below the "Globigerina Limestone", Sara Valley, Malta; early zone N9, earliest Middle Miocene: fig. 1a, sphere dissected to show last and penultimate whorls of the internal streptospire $(\times 175)$; fig. $1 \mathrm{~b}$, same specimen further dissected to reveal earliest whorl and proloculus in dorsal view $(\times 750)$.

Fig. 2. O. suturalis from Cipero formation, Trinidad; zone N12, Middle Miocene, type locality of the "Globorotalia fohsi lobata zone" of Bolli (1957, pp. 101, 105): fig. 2a dissected very early 4-chambered "globorotaline" whorl $(\times 375)$; fig. $2 b$, triradiate spine from a later chamber $(\times 1,250)$.

Fig. 3. O. saturalis from Cipero formation. Philippine Road, Trinidad; zone N9, early Middle Miocene, "Globorotalia fohsi barisanensis zone" of Bolli (1957); dissected early 4-chambered "globorotaline" whorl ( $\times 175)$.

Fig. 4. O. suturalis from early zone N9, same sample as that for specimen in fig. 1 ; fig. 4a, whole spiral stage inside its sphere $(\times 75)$; fig. $4 \mathrm{~b}$, same specimen dissected to show its early whorl $(\times 375)$.

Fig. 5. O. universa from zone N12, same sample as that for fig. 2: figs. 5a, 5b, early "globorotaline" whorls $(\times 175)$ and detail $(\times 350)$, dissected from specimen shown in fig. $5 \mathrm{c}(\times 75)$; fig. $5 \mathrm{~d}$, cluster of triradiate and rounded spines, joining the surface of a spiral chamber (fig. $5 \mathrm{c})$ to the inner surface of the enclosing sphere $(\times 1,000)$.

Fig. 6. O. universa from base of Malta Blue Clay, Fomm-ir-Rih Bay, Cliff section, Malta, middle zone N9: Fig. 6a, dissected streptospire $(\times 175)$; fig. $6 \mathrm{~b}$, same specimen, enlarged detail of early whorl $(\times 500)$.

Fig. 7. O. suturalis from $30 \mathrm{~m}$ above base of Malta Blue Clay, Fomm-ir-Rih Bay, Malta, zone N10, early Middle Miocene: fig. 7a, spherical chamber containing streptospire $(\times 100)$; fig. $7 \mathrm{~b}$, same specimen, further dissected to reveal early whorl $(\times 250)$.

Fig. 8. O. suturalis from Cipero formation, zone $\mathrm{N} 12$ (same sample as for figs. 2 and 5): fig. 8a, partly dissected whole spiral test, showing penultimate and last whorls of the streptospire $(\times 175)$; fig. $8 \mathrm{~b}$, detail of penultimate whorl $(\times 375)$, with a pseudoumbilical aperture.

Figs. 9-11. O. suturalis from Cipero formation, zone N9, (same locality as fig. 3): fig.9a, partly dissected streptospire enclosed in the spherical chamber $(\times 75)$; fig. $9 \mathrm{~b}$, enlargement of its dissected early whorl, showing the orientation of the early pseudoumbilical aperture, $(\times 250)$ (compare fig. $8 \mathrm{~b}$ ); fig. 10, another dissected specimen, showing successive whorls of the streptospire $(\times 175)$; fig. 11 , another specimen, with final spiral chamber broken to reveal the umbilical-extraumbilical aperture of the penultimate chamber $(\times 175)$.

Fig. 12. O. suturalis from Cipero formation, zone $\mathrm{N} 12$ (same locality as that for figs. 2, 5, 8): fig. 12a, streptospire inside its sphere $(\times 100)$; figs. 12b, 12c, triradiate spine clusters linking spiral chamber to inner surface of the sphere $(\times 1,750$ and $\times 1,000$ respectively $)$; fig. $12 \mathrm{c}$, same specimen, further dissected to reveal inner whorl with intra-extrapseudoumbilical aperture $(\times 250)$. 


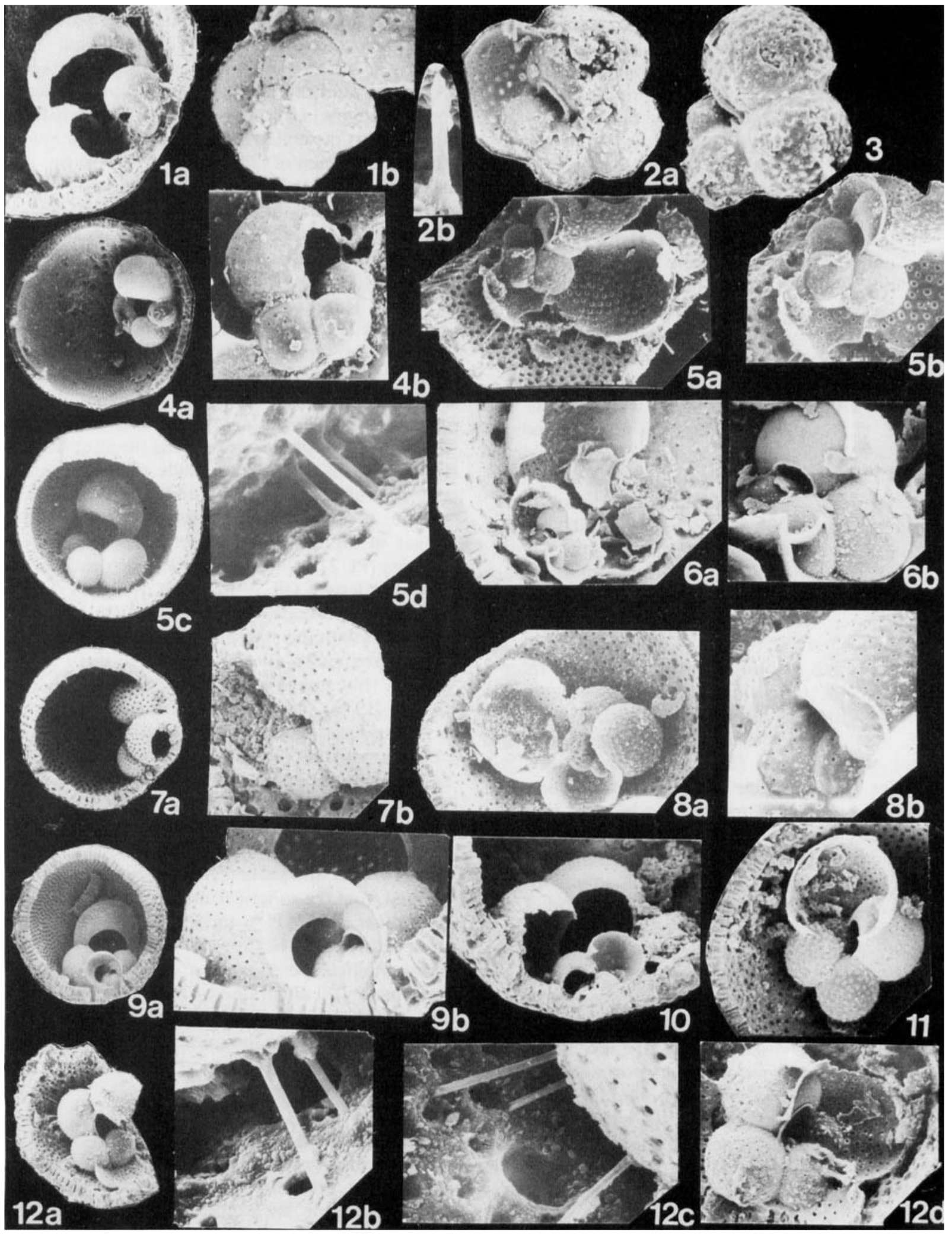


(Pl. 1, fig. 12d) (Banner \& Blow, op. cit., Pl. 2, figs. 3a, $3 \mathrm{~b}, 7)$. However, the final chamber of the Orbulina spire develops a true intra-umbilical aperture, as the coiling loosens, the final chamber ceases to embrace the umbilical area and true umbilicus develops at last (e.g. Pl. 1, fig. 11, Pl. 2, figs. 2, 4-10). The last primary aperture seems always to be intraumbilically directed, but it varies in breadth and height from a low, wholly intraumbilical arch (Pl. 2, fig. 4) to a high broad arch (PI. 2, figs. 7,9). At this growth stage, the spiral test of Orbulina resembles a Globigerina or Globigerinoides when seen in umbilical view, because the early whorls are concealed, but the chamber walls of the whole umbilical area are characteristically and primarily imperforate (Pl. 2, fig. $9 b$ ). The early whorls also show a characteristically imperforate area around the pseudoumbilicus (e.g. Pl. 1, figs. $5 b, 6 b, 8 b, 9 b, 11)$ where the imperforate area becomes that to be enclosed by the next added chamber. The umbilical area of the final spiral whorl retains its imperforate character even though no succeeding chamber (except for the final sphere) is to be added.

In both $O$. universa and $O$. suturalis, the early two whorls are smooth with scattered small perforations (about $1 \mu \mathrm{m}$ in diameter, Pl. 1, figs. $1 \mathrm{~b}, 4 \mathrm{~b}, 6 \mathrm{~b}$ ) - it is microperforate, e.g. as in adult Globigerinita. Later whorls become more coarsely perforate (perforation diameter about $2 \mu \mathrm{m}, \mathrm{Pl}$. 2, figs. $8 \mathrm{~b}, 9 \mathrm{~b}, 12$ ) and ridging develops between the perforations to initiate wide, shallow, "perforation pits" (Pl. 1, figs. 3, 7b, 8b, 12b, 12c; Pl. 2, figs. 1b, 3b). From the points of confluence of the interperforation ridges, radial spines arise; they seem to develop at the formation of the third whorl, on the umbilical side of $O$. suturalis and on both the umbilical and spiral sides of $O$. universa (PI. 1, figs. 5a, 5c, 5d, 12a, $12 \mathrm{c} ;$ PI. 2, figs. 1b, 1c, 1d, 3a, 3b, 3c). In both $O$. universa and $O$. suturalis, the spines may be cylindrical, or initially cylindrical becoming triangular in cross-section, or triangular becoming triradiate along their length. The spines develop in clusters, linking the chambers of the spire to the outermost sphere (e.g. Pl. 1, figs. 5d, 12a; Pl. 2, fig. 1b). Some of the spines, of both $O$. suturalis and $O$. universa, develop small protrusions along their lengths (Pl. 2, figs. 1c, 3c), recalling the barbs developed on the triradiate spines of Hastigerina (Walker \& Vilks, 1973, pl. 1), but the protrusions on the spines of Orbulina are much more widely spaced and are less regularly developed. The great majority of specimens of $O$. suturalis and $O$. universa from the Middle Miocene contain thick walled streptospiral tests, which are often coarsely punctate (with large perforation pits) and which usually occupy two-thirds or more of the internal diameter of the sphere.

\section{Comparison with Quaternary species of Orbulina}

$O$. suturalis was rare in the Quaternary material examined and most of the $O$. universa tests were found to be empty. Some specimens of each species were successfully dissected, enabling us to make direct comparison between our own material and that which has been described more thoroughly by Bé \& Okada (1973), Bé, Harrison \& Lott (1973) and by Vilks \& Walker (1974). As in the published description and photomicrographs, our specimens of $O$. universa were extremely thin walled throughout the coiled stage of growth. The same is true for our specimen of " $O$. suturalis" (Pl. 2, fig. 14). Even allowing for resorption (as first described by Le Calvez, 1936), which may have affected the spiral parts of both the Middle Miocene and the Quaternary specimens, the former have walls which are at least twice as thick $(2-6 \mu \mathrm{m})$ as those of the latter $(1-2 \mu \mathrm{m})$. The earliest whorl of Recent $O$. universa consists of five or more chambers (Pl. 2, figs. 12b) and is "Globorotaline" in appearance; this confirms the observations made by Bé et al. (1973) and by Vilks \& Walker (1974). In $O$. universa, the earliest spines of the evolute side appear after the first whorl; they appear to link the spiral test to the outermost sphere, suspending the streptospire inside the sphere. As the evolute side of the streptospire of "O. suturalis" is embedded in the wall of the enclosing sphere, it appears to lack spines (PI. 2, fig. 14). The spines of the last spiral whorl of $O$. universa occur in clusters (Pl. 2, fig. 13) and are either triradiate throughout their length (PI. 2, fig. 15a) or initially cylindrical, becoming triradiate distally Pl. 2, figs. $15 \mathrm{~b}, 15 \mathrm{c}$ ). This compares with the statement by Vilks \& Walker (1974) that "proximally all the spines are circular in crosssection" but agrees with the observations made by Bé \& Okada (1973). We found that the triradiate spines have a flaring base of attachment to the surface of a spiral chamber and that they can break away from the chamber surface with the spine and its base forming a single continuous "nail"-shaped entity (PI. 2, fig. 15a). This seems to be quite different from the spine structure of the outer spherical chamber, where cylindrical, "rod"-shaped spines are set into sockets in the hummocky spine bases; formed from the spherical chamber wall (well illustrated by Bé et al., 1973, Pl. 6 and P1. 8). The successive stages of apertural modification from an earlier pseudointraextraumbilical position to a later intraumbilical one, have been well illustrated by Bé et al. (1973, e.g. Pl. 4); these authors also illustrate the presence of supplementary apertures in the spiral suture of the last whorl of $O$. universa, an observation confirmed by Vilks \& Walker (1974).

\section{DISCUSSION AND CONCLUSIONS}

The spiral growth stage of both $O$. suturalis and $O$. universa, present in the earliest to middle parts of the Middle Miocene, is a streptospire in which the umbilicus is closed, terminated by a single whorl which adopts trochospirality and forms an open umbilicus. This coiling mode seems to be unique and could serve to define the 
genus even if the final spherical chamber were to be lacking. The earliest whorl, which is "Globorotaline" and non-spinose, may represent an embyronic stage of growth; it is present in Globigerinoides quadrilobatus (Huang, 1981), the species which is believed to be the first ancestor of the Orbulina lineage. The streptospiral coil of the early whorls appears to be a recapitulation of the ventrally directed streptospirality which evolved from Globigerinoides bisphericus through Praeorbulina sicana and then to $O$. suturalis in the later part of zone N8 and the base of zone N9. The same coiling mode has been retained in Quaternary $O$. universa, which therefore seems to have remained architecturally unchanged since its first evolutionary appearance. Similarly, the spines of the spiral stage of $O$. universa are either initially rounded, becoming distally triradiate, or triradiate throughout, both in the early Middle Miocene and the Quaternary. In both $O$. suturalis and $O$. universa in the Middle Miocene and in $O$. universa of the Quaternary, each spine of the spiral test is fixed to the wall surface by its own, integral boss, not inserted as a rod as are spines of the spherical chamber of Recent $O$. universa (Bé et al. 1973). The only noticeable difference between Orbulina spp. of the early Middle Miocene and $O$. universa of the Recent is the relatively thick wall (twice as thick) in the spiral chambers of the Middle Miocene. Otherwise, it seems that $O$. univers $a$ has remained unchanged since its rapid evolution ( $0.5 \mathrm{my}$ or less) from its Globigerinoides ancestor, and this "punctuation" has been followed by $16 \mathrm{my}$ of "equilibrium". It represents a "punctuated equilibrium" in which an apparent jump in speciation would occur if the later part of zone N8 were not closely sampled. There is no evidence whatever to support the suggestions made by Bandy (1969), Bandy et al. (1969) and Hofker (1969) that Orbulina universa is polyphyletic. We cannot explain, with any certainty, the photographs by Bandy (1966) of specimens resembling "Globigerinoides triloba sacculifera" and G. conglobata inside spherical Orbulina tests, but we have noticed, in our samples, that isolated Globigerinaceans, including Globigerinoides spp., can fall into and be trapped inside broken Orbulina spheres during preparation of a sample.

The evolution of $O$. suturalis from its Globigerinoides ancestor was not only shown by a change from trochospiral coiling in Globigerinoides through ventrally directed streptospirality in Praeorbulina to streptospiral to incomplete trochospiral to spherical coiling in Orbulina s.l., but also by a change from the round to rounded-triangular spines of Globigerinoides to the rounded-triradiate or fully triangular-triradiate spines of early $O$. suturalis. The spines of Praeorbulina have not yet been described; until they are, the distinction between the phylogenetic species of this continuous evolution cannot with certainty be said to be fully gradational (compare Kennett \& Srinivasan, 1983, p. 81).
Modern " $O$. suturalis" has been found to possess rounded, cylindrical spines only on its spiral test and to lack triangular-triradiated ones (Vilks \& Walker, 1974). This is quite different from the spinosity of true $O$. suturalis from the Middle Miocene. Also, although our knowledge of the ontogeny of modern "O. suturalis" remains limited, because of the rarity of such specimens, the specimen figured here (Pl. 2, fig. 14) appears to be more loosely coiled than the true $O$. suturalis ( $\mathrm{Pl}$. 1 , fig. 8a) and may be truely umbilicate and trochospiral as in Globigerinoides. Saito et al . (1981, Pl. 19) have figured a small "trochospiral" Globigerinoides, as found in abyssal North Pacific sediment, as the free-living stage of "O. universa" which lacks the spherical last chamber; Saito et al. (op. cit., Pl. 19, fig. 1d) showed that its spines are rounded-cylindrical. It is possible that this free spiral form is a stage of modern, so called " $O$. suturalis", different from both $O$. universa (with streptospirality and triradiate spines) and true Middle Miocene $O$. suturalis. Studies of cultured Orbulina (Adshead, 1967; Hemleben \& Spindler, 1983) have shown that free living, small, spiral stages of $O$. universa can repeatedly resorb and recalcify the spherical last chamber and that the spines are shed through resorption. It is tempting to suggest that there exists an unnamed species of Globigerinoides (Saito et al., 1981, P1. 19, fig. 1) which has independently acquired the ability to form a final spherical chamber in the later or last stages of its ontogeny. These spherical stages would be the so called " $O$. suturalis" of the Quaternary. Therefore, " $O$. suturalis" as currently understood may be polyphyletic although $O$. universa is not.

The same polyphyleticism may be true for " $B i$ orbulina", which is also common in the Early Miocene but rare in the Quaternary. Blow $(1956,1959,1979)$ believed Biorbulina bilobata (which has Middle Miocene type specimens) to have evolved directly from Praeorbulina transitoria in earliest Zone N9. Our preliminary examination of dissected specimens from Middle Miocene zone N10 (Pl. 2, fig. 11) suggests that some, at least, of the forms with two spherical chambers are merely true $O$. suturalis which has calcified a second spherical chamber over the first. This could be the result of recalcification of the kind observed by Hemleben $\&$ Spindler, following incomplete resorption of an earlier sphere. Vilks \& Walker (1974) dissected Quaternary bilobed specimens, which they referred to $O$. universa as the surface of the first spherical chamber inside the second one possessed triradiate spines (these authors had shown that the spherical chamber of so called "O. suturalis" from modern seas has rounded-cylindrical spines). Saito et al. (1981, p. 70, Pl. 19, figs. 4-6) show that "all variations of one-, two-, and three- chambered varieties" of $O$. universa "commonly occur in modern oceans". It is probable that these are merely specimens of $O$. universa which have calcified a second spherical 


\section{Explanation of Plate 2}

Juvenile stages in Middle Miocene and Quaternary Orbulina: SEM micrographs of $O$. universa (figs. 1, 3, 7, 10, 12-13), $O$. suturalis (figs. 2, 4-6, 8, 9, compare 14) and "Biorbulina bilobata" (fig. 11).

Fig. 1. O. universa from Malta Blue Clay, Fomm-ir-Rih Bay, Cliff section, Malta, middle zone N9, earliest Middle Miocene: fig. 1a, entire internal spire $(\times 100)$; fig. 1b, enlargement of $1 \mathrm{a}$, showing spine cluster linking cancellate surface of antepenultimate spiral chamber to inner surface of sphere $(\times 500)$; fig. 1c, same spines, rounded and triradiate, enlarged $(\times 1,750)$, some spines show incipient barbs; fig. 1d, same specimen, dissected to show dorsally spinose ealy whorls $(\times 250)$.

Fig. 2. O. suturalis from Cipero formation, Trinidad, zone N 12 (same as for Pl. 1, fig. 3), early Middle Miocene; early dissected whorl $(\times 175)$.

Fig. 3. O. universa from Cipero formation, Trinidad, zone N12 (same as for Pl. 1, fig. 2); fig. 3a, whole spire inside its final chamber $(\times 100)$; fig. $3 b$, enlargement of penultimate spiral chamber $(\times 375)$; fig. $3 c$, detail of fig. $3 b$, showing both rounded and triradiate spines with incipient barbs $(\times 1,750)$.

Figs. 4-9. Middle Miocene Orbulina showing variation in shape and extent of the final, primary, intraumbilicallydirected aperture of the spiral stage and variation in the thickness and texture of its walls. Figs. 4-5, $O$. suturalis from zone $\mathrm{N} 10$ (same locality and horizon as in P1. 1, fig. 7) (both $\times 100)$; fig. 6, $O$. suturalis from early zone N9 (same as for Pl. 1, fig. 1) $(\times 100)$; fig. 7, O. universa from middle zone N9 (same as for Pl. 1, fig. 6) $(\times 100)$; fig. 8, O. suturalis from zone N9 (same as for Pl. 1, fig. 3) $(\times 88)$; fig. 9, O. suturalis from zone N10 (same as for Pl. 1, fig. 7) $(9 \mathrm{a} \times 75,9 \mathrm{~b} \times 175)$.

Fig. 10. O, universa from base of Malta Blue Clay, middle zone N9 (same as Pl. 1, fig. 6); fig. 10a, whole spire inside its sphere $(\times 100)$; fig. $10 \mathrm{~b}$, same specimen dissected to show earlier whorls with similar intrapseudoumbilical aperture $(\times 250)$ (compare Pl. 1, fig. 8 b).

Fig. 11. "Biorbulina bilobata" from zone N10 (same as for Pl. 1, fig. 7) $(\times 100)$.

Fig. 12. O. universa from Recent sediment, Nigerian continental shelf, dissected to show earliest whorls of the spire (compare Pl. 1, fig. 1b) (fig. 12a, $\times 500$, fig. 12b, enlargement, $\times 780$ ).

Fig. 13. O. universa from Recent sediment, Nigerian continental shelf, showing spine clusters $(\times 100)$.

Fig. 14. " $O$. suturalis" from Recent sediment, Nigerian continental shelf, showing very thin, partly resorbed wall $(\times 100)$.

Fig. 15. Spines of Recent $O$. universa (same specimen as fig. 13); fig. 15a, triradiate spine with its detached base $(\times 750)$; fig. $15 \mathrm{~b}$, initially cylindrical, becoming distally triradiate, spine, attached at its base $(\times 1,750)$; fig. $15 \mathrm{c}$, cylindrical spine $(\times 5,000)$. 


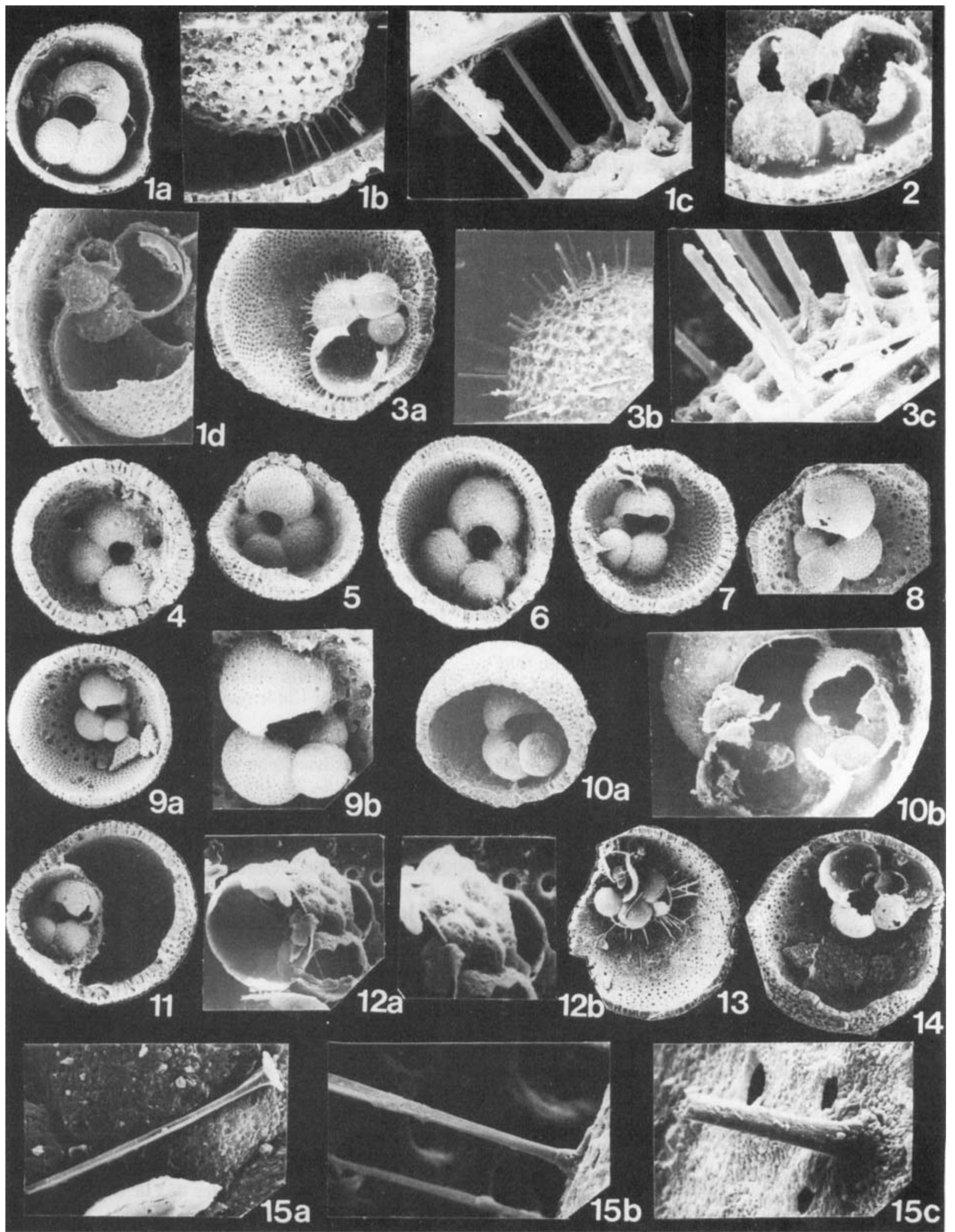


chamber (as observed by Hemleben \& Spindler, 1983), without resorption of the first one. They could be phylogenetically quite different from the thick walled, true Biorbulina bilobata of the Middle Miocene.

Finally, it is interesting to note that the first, embryonic whorl of Orbulina is microperforate and not spinose. Huang (1981) has shown the presence of a similar embryonic stage in species as diverse as Globigerinoides sacculifer (vel. G. quadrilobatus) and Neogloboquadrina dutertrei. This suggests that this is an adaptive, not recapitulatory character in Neogene Globigerinacea, and that the mere retention of such a wall character into the adult would give an adult "ultrastructure" characteristic of Globigerinita and Candeina. Therefore, simple proterogenesis could explain the sudden evolution of the marked changes in adult "ultrastructure" of such forms.

\section{ACKNOWLEDGEMENTS}

We thank T. Barnard for the samples from Trinidad, collected by him under guidance of J. B. Saunders and $\mathrm{H}$. Kugler and for the samples from Malta which were collected by a party from the Postgraduate Micropalaeontology unit at U. C. L., under his direction. We thank Dr. M. B. Collins, Department of Oceanography, U. C. Swansea, and R. West for making available eastern Mediterranean deep sea cores. We are particularly grateful to British Petroleum plc and the Shell International Petroleum Company both for providing the samples from the Nigerian continental shelf and for financial support. We are grateful to A. J. Rees and M. M. Gay, U. C. L., for technical guidance.

\section{REFERENCES}

Adams, C. G. 1970. A reconsideration of the East Indian letter classification of the Tertiary.Bull. Br. Mus. nat. Hist. (Geol), 19 (3), 87-137.

Adshead, P. A. 1967. Collection and laboratory maintenance of living planktonic foraminifera. Micropaleontology, 13, $32-40$.

Australasian Petroleum Co. Pty. 1961. Geological results of petroleum exploration in Western Papua. Geol. Soc. Australia. 133 pp.

Bandy, O. L. 1966. Restrictions of the "Orbulina" datum. Micropaleontology, 12, 79-86.

Bandy, O. L., Vincent, E. \& Wright, R. C. 1969. Chronologic relationships of Orbulines to the Globorotalia fohsi lineage. Revista Española Micropaleont., 1, 131-145.

Banner, F. T. \& Blow, W. H. 1965. Progress in the planktonic foraminiferal biostratigraphy of the Neogene. Nature, 208 (5016), 1164-66.

Banner, F. T. \& Blow, W. H. 1967. The origin, evolution and taxonomy of the foraminiferal genus Pulleniatina Cushman, 1927. Micropaleontology, 13. 133-162.

Banner, F. T. \& Lowry, F. M. D. (In press). The stratigraphic record of planktonic foraminifera: evolutionary implications. Palaeontological Association, Spec. Publ.
Bé, A. W. H. 1977. An ecological, zoogeographic and taxonomic review of Recent planktonic foraminifera. In: Ramsay, A. T. S. (Ed.), Oceanic Micropaleontology, 1, 1-100.

Bé, A. W. H., Harrison, S. M. \& Lott, L. 1973. Orbulina universa d'Orbigny in the Indian Ocean. Micropaleontology, 19, 150-192.

Bé, A. W. H. \& Okada, H. 1973. A closer look at the smallest creatures in the ocean. Lamont-Doherty Yearbook, 1973, 4 pp.

Berggren, W. A. 1982. Neogene planktonic foraminiferal biostratigraphy and biogeography: Atlantic, Mediterranean and IndoPacific regions. In: Tsuchi, R. (Ed.), Pacific Neogene Datum-planes, Univ. Tokyo Press.

Berggren, W. A. \& van Couvering, J. A. 1974. The Late Neogene. Palaeogeogr., Palaeoclimat., Paleoecol., 16, 1-216.

Blow, W. H. 1956. Origin and evolution of the foraminiferal genus Orbulina d'Orbigmy. Micropaleontology, 2, 57-70.

Blow, W. H. 1957. Transatlantic correlation of Miocene sediments. Micropaleontology, 3, 77-79.

Blow, W. H. 1959. Age, correlation and biostratigraphy of the Upper Tocuyo (San Lorenzo) and Pozon formations, Eastern Falcon, Venezuela. Bull. Amer. Paleont., 39 (178), 67-251.

Blow, W. H. 1979. The Cainozoic Globigerinida, Pt. 1, 1-222. E. J. Brill, London.

Bolli, H. M. 1957. Planktonic foraminifera from the OligoceneMiocene Cipero and Lengua formations of Trinidad, B WI. U.S. Nat. Mus. Bull., 215, 97-123.

Brönnimann, P. 1951. The genus Orbulina in the OligoMiocene of Trinidad, B.W.I. Cushman Found. Foram. Res., Contr., 2, 131-138.

Eames, F. E., Banner, F. T. Blow, W. H. \& Clarke, W. J. 1962. Fundamentals of mid-Tertiary stratigraphical correlation. Cambridge Univ. Press, 163 pp.

Fleming, C. A., Hornibrook, N. de B. \& Wood, B. L. 1969. Geology of the Clifden section.N.Z.Geol.Surv.Bull. (n.s.), 79, 71-117.

Hemleben, C. \& Spindler, M. 1983. Recent advances in research on living planktonic forminifera. Utrecht Micropaleont. Bull., 30, 141-170.

Hofker, J. 1969. Have the genera Porticulasphaera, Orbulina (Candorbulina) and Biobulina a biologic meaning? Proc. First Internat. Conf. Plankt. Microfoss. 1967, 2, 279-286.

Huang. C.-Y. 1981. Observations on the interior of some late Neogene planktonic foraminifera. Jour. Foraminiferal Res., 11, 173-190.

Jenkins, D. G., Saunders, J. B. \& Cifelli, R. 1981. The relationship of Globigerinoides bisphericus Todd, 1954 to Praeorbulina sicana (de Stefani) 1952. Jour. Foraminiferal Res., 11, 262-267.

Kennett, J. P. \& Srinavasan, M. S. 1983. Neogene planktonic foraminifera: a phylogenetic atlas. Hutchinson Ross Publ. Co., Stroudsburg, $265 \mathrm{pp}$.

Le Calvez, J. 1936. Modifications du test des foraminifères pelagiques en rapport avec la réproduction: Orbulina universa d'Orbigny et Tretomphalus bulloides d'Orb. Ann. Protist, 5, 125-133.

Le Calvez, Y. 1977. Kevision des foraminifères de la collection d'Orbigny. II. Foraminifères de l'Ile de Cuba -2. Cahiers de Micropaléontologie, 2, 3-129.

Le Roy, L. W. 1948. The foraminifer Orbulina universa d'Orbigny, a suggested Middle Tertiary time indicator. Jour. Pal., 22, 500-508. 
Reiss, Z. 1960. Structure of so-called Eponides and some other rotaliiform foraminifera. Israel Geol. Sur. Bull., 29, 1-28.

Saito, T., Thompson, P. R. \& Breger, D. 1981. Systematic index of Recent and Pleistocene planktonic foraminifera. Univ. Tokyo Press, 190 pp.

Scott, G.H . 1973. Orbulina: phylogenie et derniers stades de l'ontogenie. Rev. Micropaléont., 16, 39-49.

Vilks, G. \& Walker, D. A. 1974. Morphology of Orbulina universa d'Orbigny in relation to the other spinose planktonic foraminifera. Jour. Foraminiferal Res., 4, 1-8.

Vincent, E. 1977. Indian Ocean Neogene planktonic foraminiferal biostratigraphy and its palaeoceanographic implications. In: Heirtzler et al., (Eds.), Indian Ocean Geology and Biostratigraphy, Am. Geophys. Union, 469-584.

Walker, D. A. \&. Vilks, G. 1973. Spinal ultrastructure of the planktonic foraminifers Hastigerina Thomson and Globigerinella Cushman. Micropaleontology, 3, 196-198. 